\title{
FORMULASI TABLET HISAP EKSTRAK RIMPANG TEMULAWAK (Curcuma xanthorrhiza Roxb) DENGAN BAHAN PENGISI SORBITOL DAN LAKTOSA
}

\section{Formulation of Temulawak (Curcuma Xanthorrhiza Roxb) Rhizome Extract Lozenges with Filling Ingredients Sorbitol and Lactose}

\author{
Mega Fitriya Purnama Dewi ${ }^{1 *}$, Nafisah Isnawati ${ }^{2}$ \\ ${ }^{1}$ Universitas dr. Soebandi \\ "Korespondensi Penulis : fitriyadewi436@gmail.com
}

\begin{abstract}
Abstrak
Temulawak adalah tanaman yang tumbuh berumpun, yang telah dimanfaatkan oleh sebagian masyarakat Indonesia, baik sebagai obat tradisional, sebagai pewarna maupun sebagai bahan pangan. Perlu dibuat sediaan tablet hisap agar dapat digunakan dengan nyaman dan praktis. Tujuan penelitian ini adalah untuk menguji pengaruh kombinasi bahan pengisi sorbitol dan laktosa terhadap karakteristik granul ekstrak rimpang temulawak dan terhadap mutu fifik tablet hisap ekstrak temulawak. Tablet hisap esktrak rimpang temulawak dibuat dengan campuran bahan pengisi sorbitol dan laktosa dengan konsentrasi berbeda yaitu F1 (sorbitol 5\%: laktosa 95\%), F2 (Sorbitol 10\% dan laktosa 90\%), F3 (Sorbitol 15\%: Laktosa 85\%), F4 (Sorbitol 20\% : laktosa 80\%), F5 (Sorbitol 25\%: laktosa 75\%). Tablet dibuat dengan granulasi basah. Penelitian ini menggunakan desain eksperimental laboratorium dengan melakukan pengamatan dan pencatatan hasil dari formulasi tablet hisap ekstrak rimpang temulawak (Curcuma xanthorrhiza Roxb) dengan bahan pengisi sorbitol dan laktosa. Data yang diperoleh dianalisis menggunakan SPSS versi 21 dengan metode ANOVA oneway dengan tingkat kepercayaan 95\%. Hasil dari penelitian ini yaitu konsentrasi sorbitol dan laktosa terbaik untuk menghasilkan tablet hisap ekstrak temulawak adalah konsentrasi sorbitol $(5 \%)$ dan laktosa $(95 \%)$ dengan kecepatan alir 16,5 $\pm 0,304 \mathrm{~g} / \mathrm{detik}$, persen

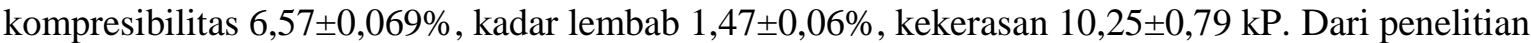
ini dapat disimpulkan bahwa penambahan konsentrasi sorbitol dapat menurunkan sifat tabletasi dan memperbaiki sifat fisik dari granul, makin tinggi konsentrasi sorbitol kekerasan tablet semakin menurun, dan meningkatkan kerapuhan dan waktu hancur tablet. Sedangkan semakin banyak konsentrasi laktosa meningkatkan sifat alir sudut diam, persen kompresibilitas dan menurunkan kadar lembab.
\end{abstract}

Kata kunci : Temulawak, Tablet hisap, Sorbitol, Laktosa

\begin{abstract}
Temulawak is a plant that grows in clumps, which has been used by some Indonesian people, both as traditional medicine, as a dye and as a food ingredient. It is necessary to make lozenges so that they can be used comfortably and practically. The purpose of this study was to examine the effect of the combination of sorbitol and lactose as fillers on the granule characteristics of the temulawak rhizome extract and on the physical quality of the lozenges of the temulawak extract. Temulawak rhizome extract lozenges were made with a mixture of sorbitol and lactose as fillers with different concentrations, namely F1 (sorbitol 5\%: lactose 95\%), F2 (Sorbitol 10\% and lactose 90\%), F3 (Sorbitol 15\%: Lactose 85\%), F4 (Sorbitol 20\%: lactose 80\%), F5 (Sorbitol 25\%: lactose $75 \%$ ). Tablets are prepared by wet granulation. This study used a laboratory experimental design by observing and recording the results of the formulation of lozenges of temulawak rhizome extract (Curcuma xanthorrhiza Roxb) with sorbitol and lactose as fillers. The data obtained were analyzed using SPSS version 21 with the one-way ANOVA method with a 95\% confidence level. The results of this study are the best concentrations of sorbitol and lactose to produce lozenges of temulawak extract are concentrations of sorbitol (5\%) and lactose $(95 \%)$ with a flow rate of $16.5 \pm 0.304$ g/second, percent compressibility $6.57 \pm 0.069 \%$, moisture content $1.47 \pm 0.06 \%$, hardness
\end{abstract}

Submit / unggah : 22 Oktober 2021, Accepted : 23 Desember 2021

Website : jurnal.stikespamenang.ac.di |Email : jurnal.pamenang@gmail.com 
$10.25 \pm 0.79 \mathrm{kP}$. From this research, it can be concluded that the addition of sorbitol concentration can decrease the tableting properties and improve the physical properties of the granules, the higher the sorbitol concentration, the lower the tablet hardness, and increase the friability and disintegration time of the tablets. Meanwhile, the more lactose concentration increases the flow angle of repose, the percent compressibility and reduces the moisture content

Keywords : Temulawak, Lozenges, Sorbitol, Lactose Keywords : Temulawak, Lozenges, Sorbitol, Lactose

\section{PENDAHULUAN}

Indonesia merupakan negara tropis yang memiliki kekayaan alam berupa tanaman obat yang sangat melimpah. Salah satu jenis tanaman obat yang telah lama dimanfaatkan sebagai bahan obat ialah rimpang temulawak (Curcuma xanthoriza Roxb). Kandungan utama rimpang temulawak ialah kurkuminoid yang bersifat immunomodulator (Nurkholis et al., 2013). Imunomodulator adalah bahan obat yang mengembalikan ketidakseimbangan sistem imun. Cara kerjanya dengan mengembalikan fungi sistem imun yang terganggu (imunorestorasi) dan memperbaiki daya tahan tubuh (Khairinal, 2012). Umumnya masyarakat terdahulu hingga saat ini memanfaatkan rimpang temulawak sebagai bahan obat dengan cara direbus menggunakan air panas lalu diminum selagi hangat, cara ini kurang praktis dan efisien dalam penggunannya.

Maka dari itu perlu pengembangan secara terus menerus, agar diperoleh formulasi sediaan rimpang temulawak dalam bentuk sediaan yang lebih praktis dan memenuhi parameter kualitas serta dapat meningkatkan daya tarik masyarakat dalam mengkonsumsi obat-obatan dari bahan alam. ( Ariswati, 2010).

Tablet hisap merupakan salah satu bentuk sediaan farmasi yang relatif praktis dan mudah digunakan. Selain itu, tablet hisap juga memberikan efek yang dikehendaki secara cepat karena zat aktif secara langsung diabsorpsi melalui mukosa mulut kemudian masuk kedalam pembuluh darah (Dylan Trotsek, 2017).

Metode yang sering dipakai dalam pembuatan tablet hisap antara lain adalah metode granulasi basah. Metode granulasi basah umumnya digunakan untuk bahan obat yang mempunyai sifat alir serta kompresibilitas yang buruk. Hal ini dikarenakan metode tersebut dapat meningkatkan sifat alir, kompresibilitas dan homogenitas dari bahan-bahan penyusun tablet hisap.

Pada formula tablet hisap terdapat bahan-bahan antara lain adalah bahan pengisi, bahan pengikat, bahan pelicin, bahan pengering dan bahan pemanis Bahan pengisi yang sering digunakan untuk tablet hisap salah satunya adalah laktosa dan sorbitol. Kelebihan dari sorbitol memiliki tingkat kemanisan sekitar 50-60\% dari sukrosa dan tidak menyebabkan karies gigi sehingga aman untuk dikonsumsi (Rowe dkk, 2009). Selain itu sorbitol juga mempunyai sifat inert serta kompresibilitas yang cukup baik serta kompatibel dengan berbagai eksipien.

Kelebihan laktosa yaitu memiliki kompresibilitas yang baik, tidak berbau dan bersifat inert. Kekurangan laktosa yaitu sifat alir yang kurang baik, dapat menyerap kelembaban udara yang akan mempengaruhi sifat fisik tablet (Sulaiman, 2007). Oleh karena itu kedua bahan pengisi tersebut dikombinasikan untuk saling menutupi kekurangan masing-masing bahan dan juga agar mendapatkan massa tablet yang kompak.

\section{METODE PENELITIAN}

Penelitian inimeru pakan penelitian eksperimental laboratorium, pembuatan tablet hisap esktrak rimpang temulawak dibuat dengan variasi pada persentase campuran bahan pengisi sorbitol dan laktosa yang berbeda yaitu;

- F1 (sorbitol 5\%: laktosa 95\%),

- F2 (Sorbitol 10\% dan laktosa 90\%),

- F3 (Sorbitol 15\%: Laktosa 85\%),

- F4 (Sorbitol 20\% : laktosa 80\%),

- F5 (Sorbitol 25\%: laktosa 75\%). T

\section{Bahan Penelitian}

Bahan yang digunakan adalah ekstrak temulawak yang telah terstandar (PT. Borobudur Herbal), sorbitol, laktosa (Duchefa Biochemie), gelatin, mg stearat, aerosil (Alpha Chemika) dan talk.

\section{Prosedur Penelitian}




\section{Pembuatan larutan pengikat}

Gelatin ditimbang sesuai dengan formula dan disuspensikan dalam air dingin sebanyak $3 \mathrm{~mL}$ kemudian dipanaskan selama \pm 5 menit sambil diaduk hingga terbentuk mucilago. Mucilago ini kemudian digunakan sebagai bahan pengikat pada pembuatan granul (Anief, 2000).

\section{Pembuatan massa granul}

Pembuatan massa granul ektrak temulawak dilakukan dengan metode granulasi basah. Tujuannya agar dapat meningkatkan sifat alir dan kemampuan kempa yang dilakukan dengan cara mencampur zat aktif dengan eksipien menjadi partikel yang lebih besar dengan penambahan bahan pengikat yang tepat setelah menjadi partikel besar kemudian ditambahkan bahan pelicin. Semua bahan disiapkan dan ditimbang sesuai yang dibutuhkan. Yaitu ekstrak temulawak $150 \mathrm{mg}$, gelatin $24 \mathrm{mg}$, aerosil 4 mg, dan sorbitol, laktosa sesuai konsentrasi yang tertera pada tabel 4.2. Kemudian campur zat aktif (ekstrak temulawak), bahan pengikat (gelatin), aerosil dan menambahkan sorbitol dan laktosa sebagai bahan pengisi.

\section{Pengayakan}

granul

dan pengeringan granul

Massa granul yang terbentuk diayak dengan ayakan mesh 12 kemudian dikeringkan menggunakan oven dengan suhu $60^{\circ} \mathrm{C}$ selama 120 menit.

\section{Evaluasi Granul}

Kecepatan alir dilakukan dengan menimbang 100 gram granul kering, kemudian memasukkan granul kedalam alat uji waktu alir yang berupa corong yang ditutup lubang keluarnya. Kemudian melepaskan sumbatnya secara bersamaan dan menghitung waktu alirnya

Sudut diam dilakukan dengan memasukkan granul kedalam corong dan mengalirkannya sehingga granul akan jatuh kedasar membentuk krucut. Sudut diam yaitu cotangent dari tinggi kerucut terhadap dasar horizontal.

Sejumlah 25gram sampel (M) dimasukkan ke dalam gelas ukur $100 \mathrm{~mL}$, lalu diukur volumenya (V bulk). Gelas ukur yang berisi sampel tersebut kemudian diketukketukkan sebanyak 300 kali dan akan didapat volume mampat (V mampat).
Pada uji ini digunakan moisture balance. Pada alat tersebut dimasukkan 1gram granul dalam alumunium foil lalu ditara dan diukur kadar airnya dengan menekan tombol start maka akan didapat persen kadar air. Pengukuran dilakukan hingga didapat kadar air yang konstan pada 3 kali pengukuran.

\section{Pencetakan Tablet}

Setelah melewati proses pengeringan dan dievaluasi kemudian granul tambahkan mg stearat sebanyak 16 gram dan talk sebanyak $40 \mathrm{mg}$ sebagai bahan pelicin, selanjutnya dilakukan pencetakan tablet dengan mesin pencetak tablet, bobot tiap tablet $800 \mathrm{mg}$.

\section{Evaluasi Tablet}

Dilihat secara visual diamati warna,bau, bentuk dan rasa dari tablet hisap yang dihasilkan.

Pengujian kekerasan dilakukan dengan mengukur tablet hisap pada alat hardness tester. Diletakkan sebuah tablet hisap pada alat dan jarum penunjuk berada pada skala 0 . Dengan mengatur ulirnya. Tablet hisap akan terjepit semakin kuat dengan menaikkan tekanan tablet secara lambat yang ditransfer melalui sebuah per. Sampai akhirnya tablet tersebut pecah.

Pertama-tama bersihkan 20 tablet dari debu yang melekat pada tablet timbang 20 tablet tersebut, kemudian dimasukkan dalam alat friabilator. Putar sebanyak 100 putaran atau putar selama 4 menit dengan kecepatan $25 \mathrm{rpm}$. Kemudian tablet dikeluarkan dari alat dan dibersihkan dari debu dan ditimbang lagi.

Uji waktu hancur dilakukan dengan memasukkan 6 buah tablet hisap kedalam alat uji yang terdiri dari keranjang dan berisi 6 silinder plastik yang terbuka bagian atasnya dan tertutup bagian dasarnya dengan pengayak 10 mesh. Keranjang di isi dengan air suling bersuhu $37^{\circ} \mathrm{C}$ dan volumenya diatur sedemikian rupa. Tablet yang berada didalam keranjang dinaik turunkan secara teratur 2932 kali per menit dengan gerakan kebawah berjarak tidak kurang dari 2,5 $\mathrm{cm}$ dari dasar wadah (Rondonuwu et al, 2017) .

\section{Metode pengolahan data}

Analisis data yang digunakan pada penelitian ini yaitu uji ANOVA One Way menggunakan Software SPSS versi 22. Uji ANOVA One Way adalah jenis uji statistika 
parametrik dengan tujuan untuk mengetahui ada tidaknya perbedaan rata-rata anatara lebih dari dua group sampel yang ditunjukan berdasarkan nilai signifikansi $\geq 0.05$. Apabila hasil perhitungan uji ANOVA menunjukkan adanya perbedaan yang bermakna maka dilanjutkan dengan uji LSD untuk menentukan perbedaan atau pengaruh perlakuan terhadap parameter uji antar formula (Sugiyono, 2006).

\section{HASIL DAN PEMBAHASAN}

Evaluasi Granul

Tabel 1 Evaluasi Granul

\begin{tabular}{lllll}
\hline Formula & $\begin{array}{l}\text { Keceppatan } \\
\text { alit }(g \text { detik })\end{array}$ & $\begin{array}{l}\text { Sudud diam } \\
\left({ }^{\circ}\right)\end{array}$ & $\begin{array}{l}\text { Persen } \\
\text { Kompresibilitas } \\
(\%)\end{array}$ & $\begin{array}{l}\text { Kadar } \\
\text { lembab }(\%)\end{array}$ \\
\hline F1 & $16,5 \pm 0,304$ & $23,01 \pm 0,416$ & $6,57 \pm 0,069$ & $1,47 \pm 0,06$ \\
F2 & $14,75 \pm 0,22$ & $25,31 \pm 0,242$ & $7,27 \pm 1,572$ & $1,78 \pm 0,04$ \\
F3 & $13,92 \pm 0,244$ & $25,24 \pm 0,845$ & $7,58 \pm 1,785$ & $1,783 \pm 0,040$ \\
F4 & $13,41 \pm 0,200$ & $24,82 \pm 0,425$ & $8,906 \pm 0,184$ & $1,853 \pm 0,075$ \\
F5 & $13,96 \pm 0,139$ & $24,65 \pm 0,080$ & $8,906 \pm 0,184$ & $1,976 \pm 0,015$ \\
\hline
\end{tabular}

Pada Tabel 1 menunjukkan kelima formula memenuhi persyaratan kecepatan alir yaitu yaitu > $10 \mathrm{~g} /$ detik (Sulaiman, 2007). Formula 1 memiliki nilai 16,5 g/detik lebih baik dari formula lain. Berdasarkan hasil uji, formula dengan konsentrasi laktosa lebih banyak akan menghasilkan kecepatan alir yang lebih baik dibandingkan granul dengan konsentrasi sorbitol lebih banyak. Karena laktosa dapat menyerap kelembapan udara sehingga antar partikel serbuk memiliki ikatan yang kuat satu sama lain sehingga dihasilkan granul dengan ukuran yang besar. Granul dengan ukuran besar akan memiliki kontak antar granul yang kecil, sehingga memiliki kecepatan alir yang baik.

Pada uji sudut diam kelima formulasi memenuhi persyaratan sudut diam yang baik $\leq 30^{\circ}$ dan sudut diam $\geq 40^{\circ}$ menunjukkan hasil yang kurang baik (Banker \& Anderson, 1994). Semakin besar sudut diam, granul semakin sulit mengalir. Granul dengan konsentrasi laktosa lebih banyak cenderung membentuk fines karena daya ikat antar partikel kecil, sehingga menyebabkan ukuran granul menjadi lebih kecil.

Ukuran granul yang lebih kecil cenderung memiliki sifat alir yang kurang baik karena luas kontak antar granul menjadi luas, namun pada hasil yang didapat formula dengan konsentrasi laktosa lebih banyak memiliki sudut diam kecil sehingga sifat alirnya baik, hal ini dikarenakan sifat laktosa dapat menyerap kelembaban udara dimana granul yang dihasilkan akan memiliki ukuran yang besar sehingga kontak antar granul kecil. Sudut diam yang terbentuk dipengaruhi oleh bentuk, ukuran dan kelembaban relatif granul.

Uji kompresibilitas dengan syarat kurang dari $20 \%$. Sehingga dapat dikatakan bahwa semua granul ekstrak temulawak memiliki kemampuan alir yang sangat baik. Namun dari kelima formula tersebut, formula 1 yang paling baik. Nilai persen kompresibilitas dipengaruhi oleh BJ nyata, ukuran partikel dan kadar lembab granul. Granul dengan konsentrasi sorbitol lebih banyak dapat menyerap lembab yang didukung oleh sifat bahan yang higroskopis, sehingga tablet yang dikempa menjadi agak lembab. Peningkatan konsentrasi laktosa akan meningkatkan nilai BJ nyata granul. Granul yang nilai BJ nyatanya rendah akan memiliki niai persen kompresibilitas yang tinggi dan bersifat lebih kohesif.

Pada uji kadar lembab menunjukkan kelima formula memenuhi persyaratan kadar lembab granul yaitu yaitu 1-5\%. Formula 1 adalah formula yang paling baik kadar lembabnya dibanding dengan formula lain dan formula 5 mempunyai tingkat kelembaban paling tinggi sehingga wakyu alirnya lambat dan kecepatan alirnya kecil. Semakin banyak konsentrasi sorbitol maka kelembaban semakin tinggi, kelembaban yang tinggi akan mengakibatkan granul akan saling mengumpul dan memperlambat waktu alir. Nilai kelembaban granul menurun secara signifikan saat konsentrasi sorbitol ditambahkan sebanyak 5\%-25\%.

\section{Evaluasi Tablet}

Tabel 2 Evaluasi Tablet

\begin{tabular}{|c|c|c|c|c|c|c|c|}
\hline \multirow[t]{2}{*}{ Formula } & \multicolumn{4}{|c|}{ Organoleptis } & \multirow[t]{2}{*}{ Kekerasan } & \multirow[t]{2}{*}{ Kerapuhan } & \multirow{2}{*}{$\begin{array}{l}\text { Waktu } \\
\text { hancur }\end{array}$} \\
\hline & Bentuk & Warna & Rasa & Aroma & & & \\
\hline 1 & $B$ & & $\mathrm{AP}$ & & & & $5573+15$ \\
\hline $\mathrm{F} 2$ & & & AP & KT & & & \\
\hline $\mathrm{Fy}$ & & & AP & KT & & & 1,69 \\
\hline F4 & & & AP & KT & $9,15 \pm 0,625$ & & $57,59 \pm 0$, \\
\hline F5 & B & CT & AP & KT & $8,9 \pm 0,87$ & $0,09 \pm 0,06$ & $57,68 \pm 0,2$ \\
\hline
\end{tabular}

Keterangan :

B: Bulat

CM : Coklat Muda

CT : Coklat Tua 
$\begin{array}{ll}\text { AP } & : \text { Agak Pahit } \\ \text { KT } & \text { : Khas Temulawak }\end{array}$

Pada tabel 2 dapat dilihat bahwa pengamatan organoleptis tidak terdapat perbedaan yang mencolok dari kelima formula. Bentuk tablet bulat, warnanya coklat muda hingga tua dengan aroma khas temulawak dan rasa agak pahit.

Kekerasan tablet menunjukkan bahwa semua formula memenuhi syarat kekerasan yaitu 7-14 kg (Cooper and Gunn's, 1975). Pada F1 dengan konsentrasi laktosa yang paling banyak formula ini mempunyai kekerasan yang paling tinggi, ini disebabkan karena laktosa mempunyai sifat menyerap air dari udara yang rendah. Granul akan menjadi sedikit lembab sehingga ikatan antar partikelnya akan semakin kuat pada saat dikempa dan menghasilkan kekerasan tablet yang tinggi.

Uji kerapuhan tablet kelima formula memenuhi persyaratan kerapuhan tablet yaitu tablet yaitu kurang dari atau sama dengan $0,8 \%$ (Voigt, 1995). Formula 4 adalah formula paling baik dalam kerapuhan talet. Kerapuhan dipengaruhi karena konsentrasi bahan pengisi sorbitol dan laktosa yang berbeda. Tablet dengan konsentrasi sorbitol paling banyak akan memperkuat ikatan antar partikel, sehingga dapat menahan pengikisan pada tablet.

Uji waktu hancur tablet pada Tabel 2 menunjukkan kelima formula memenuhi persyaratan waktu hancur yaitu tablet waktu hancur dalam waktu 30 menit atau kurang (Lachman, dkk., 1994). Urutan tablet yang mempunyai waktu hancur paling cepat adalah $\mathrm{F} 1>\mathrm{F} 2>\mathrm{F} 4>\mathrm{F} 5>\mathrm{F} 3$ dari data waktu hancur tersebut terlihat bahwa granul dengan konsentrasi sorbitol $15 \%$ dan laktosa $85 \%$ atau formula 3 mempunyai waktu hancur yang paling lama. Hal itu disebabkan karena sorbitol merupakan bahan yang memiliki kemampuan pengikat yang kuat (Owen, 2006). Sifat tersebutlah yang mempengaruhi kekerasan pada tablet hisap. Kekerasan juga berpengaruh pada waktu hancur tablet, semakin keras tablet tersebut maka akan semakin lama waktu hancurnya.

\section{KESIMPULAN dan SARAN}

Dari hasil penelitian yang telah dilakukan dapat disimpulkan bahwa semakin meningkat konsentrasi sorbitol maka karakteristik granul dan kekerasan tablet semakin menurun, semakin meningkat konsentrasi sorbitol maka kerapuhan dan waktu hancur tablet semakin meningkat.

Dari hasil penelitian ini selanjutnya diperlukan adanya pengembangan formula dengan menambahkan bahan pemanis sehingga nantinya tablet hisap yang dihasilkan akan memiliki rasa yang manis.

\section{DAFTAR PUSTAKA}

Afifah, E., dan Tim Lentera. 2003. Khasiat dan Manfaat Temulawak Rimpang Penyembuh Aneka Penyakit. Agromedia Pustaka. Jakarta.

Anief, M, 2000, Farmasetika, 2000, Gadjah Mada University Press, Yogyakarta

Banker, S.G., And Anderson, R.N., 1986, Tablet In Lachman, L. Lieberman, The Theory And Practice Of Industrial Pharmacy, 3 Rd Ed., Lea And Febiger, Philadelphia. 643704.

Cooper, J. W., And Gunn, 1975, Dispending For Pharmaceutical Students, Twelfth Ed.10, Pitman Medical Publishing Co. Ltd, London.

Dylan Trotsek (2017) 'Jurnal Resep Bahan Alam', Journal Of Chemical Information And Modeling, 110(9), Pp. 1689-1699.

Khairinal, 2012. Efek Kurkumin Terhadap Proliferasi Sel Limfosit Dari Limpa Mencit Ch3 Bertumor Payudara Secara In Vitro. Thesis. Depok: Jurusan Kimia, Fakultas Matematika Dan Imu Pengetahuan Alam, Universitas Indonesia.

Lachman, L., Lieberman, H.A., And Kanig, J.L., 1994, Teori Dan Praktik Industri Farmasi, 643-705, Diterjemahkan Oleh Suyatmi, S.,Jakarta, Ui Press

Nurkholis Dr, Tantalo S, Santosa Pe. 2013. Pengaruh Pemberian Kunyit Dan Temulawak Melalui Air Minum Terhadap Titer Antibody Ai, Ibd, Dan Nd Pada Broiler. Lampung: Fakultas Pertanian Universitas Lampung

Owen, S.C., 2006, Sorbitol, in : Rowe, R.C., Sheskey, P.J., and Owen, S,C., Handbook of Pharmaceutical Excipients. Fifth edition, 718-721, Phamaceutical Press, London Chicago

Rondonuwu, C., Citraningtyas, G. and Sudewi, S. (2017) 'Formulasi Tablet Hisap Serbuk Buah Mangga Dodol (Mangifera Indica L) Dengan Menggunakan Metode Granulasi Basah', Pharmacon, 6(4), pp.

Rowe, R.C. Et Al. (2009). Handbook Of Pharmaceutical Excipients, 6th Ed, The Pharmaceutical Press, London. 
Sugiyono. 2006. "Metode Penelitian Kuantitatif Kualitatif Dan R\&D”. Bandung: Alfabeta.

Sulaiman, T.N.S., 2007, Teknologi \& Formulasi Sediaan Tablet, Pustaka Laboratorium Teknologi Farmasi, Fakultas Farmasi, Universitas Gadjah Mada, Yogyakarta. 56 $59,198-215$. 